\title{
Marian Machinek
}

\section{Reproductive Rights versus the Christian Culture of the Body Two Different Perspectives}

\begin{abstract}
The comparison between the concept of sexual and reproductive rights and the idea of gender and the Christian culture of the body with its personalist anthropology reveals their essential differences. The concept of reproductive rights is permeated with individualism, where sex identity can be freely defined, and sexual activities of individuals - provided that they stay within the boundaries of law-are not subjected to any moral norms. The main point of the disagreement between the concept of reproductive rights and the Christian culture of the body concerns the meaning of human corporeality. For the former, human body is, in a certain way, an 'outside' of the self-determining subject. According to the latter view, human body participates in man's dignity as his constituent dimension. Another difference revolves around the meaning of sexual activity. Efforts to force implementation of sexual and reproductive rights, along with gender informed law and culture, are dangerous to the fundamental group unit of society - the family-based on the marriage between man and woman.
\end{abstract}

Key word s: human rights, reproductive and sexual rights, Christian culture of the body, encyclical Humanae Vitae, gender, personalistic concept of person

\section{Introduction}

In 2018, there were numerous celebrations marking the anniversaries of promulgation of three momentous documents, which are of interest to this paper. Seventy years ago, in 1948, the United Nations proclaimed a milestone docu- 
ment in the modern history of our civilization: Universal Declaration of Human Rights. Its signatories called it the reaction of the outraged "conscience of mankind" to the barbarous acts committed during the Second World War, ended barely three years before. ${ }^{1}$ The Declaration has become the springboard and the point of reference for various later initiatives addressing basic human rights.

Twenty years later, in 1968, the public heard about two other extremely important documents. First, the Proclamation of Teheran, passed as the Final Act of the First International Conference on Human Rights, organized by the United Nations in Teheran. ${ }^{2}$ Its nineteen articles aspired to demonstrate the importance of human rights and give them necessary prominence in the lives of individuals and societies. The Proclamation reflects twenty years of lively discussions on human rights, and foreshadows later disagreements over their interpretations and efforts to work out further details. The third document of interest to us, proclaimed in the same memorable year 1968, was the encyclical by Pope Paul VI: Humanae Vitae (Of Human Life), subtitled: On the Regulation of Birth. ${ }^{3}$ No other Church document of the last century caused such fierce controversies, triggered by its refusal to accept artificial methods of birth control. It came less than ten years after the invention of a contraceptive pill, ${ }^{4}$ and it was immediately labelled as an attack on modernity, social advance, and the progress of medical science. It was precisely what this paper calls the Christian culture of the body, that found its expression in pope's arguments for the defence of the carnal and spiritual integrity of man in matters related to his sex, sexuality, and procreation, and his relevant moral obligations. Papal stance was in an opposition to the anthropological concept of man, on which present-day demands for the affirmation of the reproductive and sexual rights of minorities are based.

The objectives of this article are to identify and discuss some of the anthropological and ideological origins of the theory of sexual and reproductive rights, compare this theory with the Christian notion of the culture of the body, and demonstrate the most contested differences between these two concepts.

1 The Universal Declaration of Human Rights was adopted by the United Nations General Assembly at its third session on December 10, 1948, in Paris, in France.

2 The Conference met from 22 April to 13 May 1968.

3 The encyclical Humanae Vitae, written by Paul VI, was promulgated on 25 July 1968.

4 The U.S. Food and Drug Administration (FDA) approved the birth control pill for contraceptive use in 1960. 


\section{An Important Redefinition of Terms}

The perusal of various papal documents and pronouncements, starting with $R e$ rum Novarum by Leo XIII (1891), can create an impression that the advocacy of human rights has been the common concern of the Catholic Church and international community for decades. Later popes-John XXII in Pacem in Terris (1963), Paul VI in his address to the United Nations General Assembly in 1965, and John Paul II in his encyclical letters Redemptor Hominis (1979), Laborem Exercens (1981), Sollicitudo Rei Socialis (1987) and Centesimus Annus (1991), and his numerous speeches and addresses — pledged Church's support for activities defending and promoting human rights, abandoning her previous reserve, caused by their antireligious and anticlerical overtones, inherited from the French Revolution. ${ }^{5}$ Whence does the dissonance between the numerous UN endorsed programs for the recognition of certain individual claims as human rights (especially those concerning sexual and reproductive rights), and the teaching of the Catholic Church, come from? What makes some people see her as the opponent of human rights? In an attempt to answer these troubling questions, let us first briefly examine the evolution of the idea of human rights. Reading the Universal Declaration of Human Rights one cannot fail to recognize their origins. They are all firmly anchored in man's rational nature. Every human being has human rights; he is born with them and he dies with them. He never forfeits them. They are inherent and irrevocable. As such, they are not dependent on any official, formal consent of any human authority. They do not need it to exist and be valid. Thus says the Universal Declaration of Human Rights on family: "Men and women of full age, without any limitation due to race, nationality or religion, have the right to marry and to found a family. They are entitled to equal rights [...]. Marriage shall be entered into only with the free and full consent of the intending spouses. The family is the natural and fundamental group unit of society and is entitled to protection by society and the State" (Article 16). ${ }^{6}$ Similarly, the Proclamation of Teheran: "The protection of the family and of the child remains the concern of the international community. Parents have a basic human right to determine freely and responsibly the number and the spacing of their children" (Article 16). ${ }^{7}$ The rights of parents concerning their procreative

${ }^{5}$ See: Jerzy Gocko, "O prawach człowieka i niektórych kontrowersjach z nimi związanych," in Prawa człowieka. W 60. rocznice uchwalenia Powszechnej Deklaracji Praw Człowieka przestanie moralne Kościoła, ed. Krzysztof Jeżyna and Tadeusz Zadykowicz (Lublin: Wydawnictwo KUL, 2010), 40-42.

${ }^{6}$ Powszechna Deklaracja Praw Człowieka, http://www.unesco.pl/fileadmin/user_upload/ pdf/Powszechna_Deklaracja_Praw_Czlowieka.pdf, accessed January 30, 2019.

${ }^{7}$ Proclamation of Teheran, Final Act of the International Conference on Human Rights, Teheran, http://hrlibrary.umn.edu/instree/12ptichr.htm, accessed January 30, 2019. 
decisions, formulated as in the quoted texts, are clear. At this level of generality, they are in concord with the Catholic vision of marriage and family.

A shift in understanding human rights in relation to man's sexuality became visible in the 1960s, with the appearance of the idea of "reproductive health" in publications relating to gynecology and birth control. ${ }^{8}$ The latter term was originally meant for programs of control and reduction of the global birth rate. It is present in documents produced by international conferences on women ${ }^{9}$ and global population. ${ }^{10}$ Focus on health related rights, including protection of "reproductive health," led to the formulation of the term: "reproductive rights." Both names are today closely related and dependent on each other for their definitions.

The International Conference on Population and Development in Cairo, Egypt, in 1994 laid a great stress on sexual and reproductive health and reproductive rights. There was a strong lobbying for access to contraception and abortion as the important element of reproductive health and reproductive rights, a redefinition of marriage, and granting equal marriage rights to all kinds of unions. The draft of the final document prompted a strong reaction from the Vatican. Pope John Paul II sent a letter to the heads of states participating in the conference, expressing his great concern about plans for pushing ahead with making right to unlimited abortion into law, and protesting against a "lifestyle typical of certain fringes within developed societies, which are materially rich and secularised." 11 In the final document of the conference, there is a passage disclaiming abortion as a method of birth control, and recommending States to devise means to assist women in avoiding recourse to abortion. ${ }^{12}$ But the term reproductive health was broadened to include not only concern for woman's health before and during pregnancy, but her general sexual well-being too. The latter meant access to legal methods of birth control; in fact, to contraceptives and abortion. ${ }^{13}$

${ }^{8}$ Bioethics Reflection Group of COMECE, 2010, "The Term 'Sexual and Reproductive Health' and Its Meaning at International and European Levels," in Science \& Ethics. Collection of Opinions Prepared by the Bioethical Reflection Group (COMECE: Brussels, 2012).

9 The first international conferences on women were organised in Mexico (1975), Copenhagen (1980), and Nairobi (1985).

${ }^{10}$ The first international conferences of this type were organized in Bucharest (1974) and Mexico (1984). See: Janusz Balicki, "Globalna polityka ludnościowa. Konflikt Północ - Południe," Saeculum Christianum 7(2) (2000): 221-224.

${ }^{11}$ John Paul II, 1994, "The International Community. List do Głów Państw na Międzynarodową Konferencję na temat Zaludnienia i Rozwoju w Kairze," March 19, in Posoborowe Dokumenty Kościoła katolickiego o matżeństwie i rodzinie, Vol. II, ed. Kazimierz Lubowicki (Kraków: Wydawnictwo M, 1999), 107.

12 Report of the International Conference on Population and Development, Cairo September 5-13, 1994, No. 7.24, accessed January 30, 2019, http:/www.un.org/en/development/desa/popula tion/events/pdf/expert/27/SupportingDocuments/A_CONF.171_13_Rev.1.pdf.

${ }^{13}$ Cf. Marian Pokrywka, "Prawa reprodukcyjne," in Prawa człowieka. W 60. rocznicę uchwalenia Powszechnej Deklaracji Prawa Człowieka - przesłanie moralne Kościoła, ed. Krzysztof Jeżyna and Tadeusz Zadykowicz (Wydawnictwo KUL: Lublin, 2010), 120-122. 
The Fourth World Conference on Women: "Action for Equality, Development and Peace" in 1995 in Beijing, in China, took another step forward by planting the ideas of reproductive health and reproductive rights firmly into the public conscience. Its final documents - the Beijing Declaration and the Platform for Action - state in numerous passages that health and reproductive rights are parts of universal human rights. ${ }^{14}$ The Platform for Action lists "unsafe abortions" as one of the threats to sexual and reproductive health. ${ }^{15}$ Though it reiterates the recommendation of the International Conference on Population and Development in Cairo (1994) that abortion should not be promoted as a method of family planning, and condemns induced abortion, it urges the governments of the countries where abortion is legal to make it accessible and safe. ${ }^{16}$ Here is the catch: abortion is safe only if it is legal. So, to make it safe, it must be made legal first.

The Conference in Beijing made another important inroad into public and legislative discourse on reproductive rights by inserting into it a certain key concept: "gender-based identity." The term appeared for the first time in the late 1960s. ${ }^{17}$ It can be seen as the anthropological basis for sexual and reproductive rights. It postulates precedence of culturally conditioned gender over biologically determined sex. Though the latter remains the starting point for every human being, it never rises to a status of a normative reference point. Today, every reflection on sexual and reproductive health and reproductive rights must demonstrate sensitivity to gender-related issues. It must be gender-sensitive. ${ }^{18}$

In the last twenty years, reproductive rights and gender-based perspectives have been frequently evoked in many international documents, recommendations, political agendas, and legal acts. Their acolytes want them to be accepted as imperatives in all matters related to parenthood; and they want it on the global scale. The gap between partisans of this process and defenders of the Christian culture of the body and the teaching of the Catholic Church, is growing wider. It should be said though that the terms themselves are by no means the cause of this lamentable state of affairs. There would be no major disagreements between modern movements for the advocacy of human rights and the Christian under-

14 "IV Światowa Konferencja w sprawie Kobiet, Platforma Działania" No. 95, http://www. tus.org.pl/uploads/dokumenty/raport_czwartej_swiatowej_konferencji_w_sprawie_kobiet_pe kin_1995.pdf, accessed January 30, 2019.

${ }^{15}$ Ibid., No. 93, 106 (j), 109 (i).

${ }^{16}$ Ibid., No. 106 (k).

${ }^{17}$ Robert J. Stoller, an American psychiatrist, is credited with the introduction of the term gender into the academia. See: Robert J. Stoller, Sex and Gender. On the Development of Masculinity and Femininity (New York: Carnak Books, 1968).

18 "IV Światowa Konferencja w sprawie Kobiet, Platforma Działania," No. 107. Often enough attempts are made to reduce gender-based approach to justified claims for social equality of men and women. Nevertheless, it is difficult to use gender merely as a symbol of feminist postulates, with no regard for the biological sex and the concept of man. 
standing of those rights, if reproductive rights meant, for all interested parties, freedom from external pressure and responsible sexual activities aiming at conception of a child. Undoubtedly, the concept of gender does correctly recognize some cultural determinants. The teaching of the Catholic Church acknowledges it. The problem stems from ideologically driven narrowing of their definitions and forging them into weapons for redefining marriage, universal acceptance of contraceptives and unlimited right to abortion.

\section{Anthropological Difference between the Doctrine of Sexual and Reproductive Rights and the Christian Culture of the Body}

At the core of the anthropological difference mentioned above are entirely different visions of man, represented by the opposing doctrines. The Church's view was succinctly expressed in the reservations of the Holy See to the resolutions of the Cairo Conference (1994):

With reference to the terms "sexual health," "sexual rights," "reproductive health" and "reproductive rights," the Holy See considers them essential to the all-encompassing (holistic) understanding of health; they refer-each in its own way - to the entire human person: his or her identity, mind and body. They aid sexual maturity and reciprocal love and shared decision-making, that is, the qualities that make marital relationships in harmony with moral precepts. ${ }^{19}$

What is at stake is not an obscure legal ruling, or one or another particular aspect of private or social life, but the very vision of man.

\section{Shift towards Individualism}

The concept of sexual and reproductive rights reflects the opinions that people are totally free in shaping their sexual identities. It lays great stress on self-determination, to which moral autonomy is crucial - the notion central to

19 “Zastrzeżenia Stolicy Apostolskiej," L'Osservatore Romano (Pl) 15(11) (1994): 48 [Trans. M.M.]. 
every anthropology. In the context of the Christian culture of the body, moral autonomy represents the ability to perform moral discernments and follow their conclusions (knowing good from evil). As one of the constituent parts of human dignity, moral autonomy calls for legal frameworks protecting that dignity from hostile forces. That is what human rights are, actually. The doctrine of sexual and reproductive rights leans in the direction of granting an absolute primacy to individual freedom. Towering over everything else, individual freedom no longer recognizes good, but defines it autocratically.

Studying the history of the movements for the protection of human rights, and their use of the terms reproductive health and reproductive rights, one can notice the moment when a significant shift towards individualism occurred. Initially, their adherents used to employ them in the context of marriage and family, or couples. Later, they turned their attention to individual rights, especially women's rights. Parenthood ceased to be viewed as shared responsibility of couples in favor of individual projects of men or women.

That shift is present in the probably most contended issue: "The right to abortion," treated as an element of the reproductive health and the right of women to self-determination. In many countries where abortion was permissible, but regarded against the law, it was exempted from punishment because of exceptional circumstances of pregnant women. Such policy was expected to kill two birds with one stone: Satisfy the need for legal condemnation for killing the unborn child, and express sympathy with the postulates to accord pregnant women exclusive responsibility for their children. For instance, abortion in Germany is against the law, but not punishable (rechtswidrig aber straffrei). ${ }^{20}$ Right to abortion is no longer a concession, but the valid part of reproductive rights, closely linked to the fundamental human rights. Gone is the moral iniquity of abortion, expelled by the woman's right to make sovereign decisions about life and death of the child in her womb. This is bound to generate serious social consequences. For instance, for health professionals. Today, no physician or other health professional may be compelled to perform an abortion. But, if the right to abortion becomes part of reproductive rights and-by extension-human rights, every physician refusing to perform it can be accused of violation of human rights. In legal practice, it is comparable to the use of torture, or other forms of cruel treatment. In some European countries, doctors refusing abortion $^{21}$ already experience many problems caused by the doctrine of sexual and reproductive rights.

The Christian culture of the body is based on the personalist view of the human person. It acknowledges the importance of self-determination as person's

${ }^{20}$ See: Bundesministerium für Justiz und für Verbraucherschutz, Strafgesetzbuch (StGB) $\S 218-218 a$, https://www.gesetze-im-internet.de/stgb/_218.html, accessed January 31, 2019.

${ }^{21}$ Cf. Bogdan Chazan, Prawo do życia. Bez kompromisu. Interview with Maciej Müller (Kraków: Wydawnictwo WAM, 2014). 
potentiality and moral obligation. But, it places itself in the context of the relationship. The relational dimension of man is as fundamental as his autonomy. ${ }^{22}$ The right to self-determination, in the context of sexuality and reproduction, is not viewed simply as the freedom to self-expression, restricted only by law, and not by any other natural or objective moral norms, whatever the interpretation of the latter. In the context of the Christian culture of the body, procreative issues are always considered in the light of the shared responsibility of the married couple. Marriage is essential for establishing strong and stable bonds between parents, creating environments that are conducive to the proper upbringing of their offspring. Such environments cannot be regarded as individual projects of autonomous persons, but as the expression of the shared responsibility of the couples and the fruits of their reciprocal love. In Christianity, we do not talk of reproduction (that is, satisfying one's sexual needs), but procreation (that is, passing on life as the fruit of the conjugal love). There is no "right to child" that could be made into an element of reproductive rights, simply because no human being can be the object of the rights of another human being. If reproductive rights may be mentioned in the context of the Christian culture of the body at all, it could be only in reference to the right of parents to decide the number and spacing of their children. ${ }^{23}$ When talking about rights of parents we must not forget about their responsibilities for the life of their child. Direct abortion is the negation of child's fundamental human right to life. Obviously then, it cannot be accepted as an element of reproductive rights.

\section{The Meaning of the Human Corporeality}

The emphasis on individual preferences in the doctrine of reproductive rights is what makes it so incompatible with the Christian culture of the body. Both concepts understand human corporeality differently. One may have an impression that the anthropological concept, on which the doctrine of sexual and reproductive rights rests, is tinted with the anthropological dualism. The essence of manhood seem to consist of the self-determining human mind, to which corporeality is something quite external: an object that can be used; a service life that can be made use of; a plastic structure that can be molded at will. It is very clear in the gender concept of human sexuality as the product of culture. According to gender-driven view of human history, culture used to be employed

${ }^{22}$ See: Ellio Sgreccia, Personalist bioethics. Foundations and Applications (Philadelphia: NCBC, 2012), 384-387.

${ }^{23}$ Pastoral Constitution on the Church in the Modern World of the Second Vatican Council calls parents "cooperators with the love of God the Creator." They are the interpreters of that love and they have the exclusive right to decide the number and spacing of their children (Gaudium et Spes, 50). 
as the rigid frame for sexual identity, imposed indiscriminately on every newborn person. Modern, liberal societies should remove those restrictions and allow autonomous subjects freely shape their own sexual self-expression. Sexual orientation and sexual identity ${ }^{24}$ are culturally conditioned and can be freely shaped, or changed, according to subject's personal preferences. Hence the drive to change law to validate the object-oriented attitude to human body and make it a lawful element of the proposed sexual and reproductive rights.

The Christian culture of the body perceives corporeality from a completely different perspective. Human person is regarded as the unity of body and spirit. Both components, body and spirit, are irreducible in their interrelation. Human person is "anima et corpore unus," in the words of the Pastoral Constitution on the Church in the Modern World Gaudium et Spes of the Second Vatican Council. ${ }^{25}$ The Christian perspective on person goes far beyond monism (which reduces man to one of his constituent parts, usually to the material one; like, for instance, in naturalism), and dualism (which acknowledges irreducible qualities of body and spirit, but does not recognize their unity-only a very loose relationship). The crucial thing is that human body participates in the dignity of person. Thus, it cannot be an object of manipulation. ${ }^{26}$

\section{Sexual Activities and Procreation}

Different views on corporeality prompt an inquiry into the relationship between sexuality and procreation. The doctrine of reproductive rights does not pay much attention to this issue. It is concerned only about their biological interdependence, important solely in the context of reproductive health. That interdependence in itself does not have any deeper meaning. Of course, self-determining persons, using their bodies to their own ends, can give it some other meanings. Sexual encounter is simply the realization of one's sexual needs, and his body a means to achieve that end. It follows that any interference with fertility (like

24 Both terms are key concepts in the gender ideology. They refer to deeply felt experience of one's corporeality and sex and the intensity of affectional, emotional, and sexual attraction to individuals of the same or opposite sex, entering into sexual relationships with them. The above definitions come from the Preamble to the Yogyakarta Principles, a list of claims to legislators composed in an Indonesian city of Yogyakarta in 2006 by a group of experts and activists interested in the rights of sexual minorities. See: https:/www.kph.org.pl/publikacje/b-y_zasady.pdf, accessed January 15, 2014.

25 Gaudium et Spes, 14.

${ }^{26}$ Cf. Jaroslaw Kupczak, Teologiczna semantyka płci (Kraków: Wydawnictwo WAM, 2013), 27-54. For more on corporeality from the Christian perspective of man as the unity of body and spirit, see: Marian Machinek, "Zur Kontroverse über die normative Dimension der menschlichen Leiblichkeit," Studia Nauk Teologicznych 8 (2013): 185-193. 
artificial contraception and abortion), ensuring as free and comfortable realization of one's sexual and reproductive needs as possible, is permissible.

This position reflects a profound cultural change caused by the application of the theory of evolution to the philosophical anthropology. One of the key premises in the theory of evolution is the concept of accident. When employed to explain man's corporeality and his biological sex, it is argued that the latter is the result of accidental evolutionary changes. Biological sex cannot be endowed with any deeper moral meaning. It follows that it is wrong to view corporeality as a reference point for moral discernment and moral conduct. Human nature-what people call it - is a vehicle, subject to changes, for the articulation of culturally conditioned social roles and models of behavior. Since both social roles and social models of behavior are culturally constructed, they must be in the same way deconstructed, reduced to their constituent parts, reinterpreted and reconstructed again, so that they fulfil the expectations of the self-determining persons. To achieve these objectives, popular perception of biological sex and sexuality must be changed first. When this process is on the way, the time will come for the entire social structures to undergo comprehensive deconstruction and reconstruction operations, so that they cease to obstruct the rights of individuals to materialize their sexual needs and preferences. ${ }^{27}$

The Christian culture of the body proposes an opposite perspective on human sexuality and biological sex. Because man is the unity of body and spirit, he exercises his freedom within his corporal nature. His sexuality is an asset to be used wisely and responsibly. It is both a gift and a task. As Karol Wojtyła puts it in his book Love and Responsibility, human body has a certain nuptial quality: its biological processes were created to express love. ${ }^{28}$ Sexuality affects man so deeply that when he makes a decision to engage in a sexual activity, he makes a decision about the person..$^{29}$

According to the Christian perspective on biological sex, sexual education should not be limited to the presentation of the anatomy and functions of reproductive organs. Neither should it be part of the fight for unlimited access to contraceptives and instruction lessons on how to use them. Its objective should rather be an introduction into the grammar of that special language: sexual act. Sexual encounter preserves its full meaning if it happens in the context of complete reciprocity of the spouses and respects and protects—not artificially

${ }^{27}$ See: Hanna-Barbara Gerl-Falkovitz, Frau - Männin - Menschin. Zwischen Feminismus und Gender (Kevelaer: Butzon \& Berker, 2009), 165-167.

${ }^{28}$ Karol Wojtyła, Miłość i odpowiedzialność (Lublin: TN KUL, 2001), 203, ft. 69.

${ }^{29}$ For more on the role of biological sex in the Christian concept of person, see: Karolina Korobczenko, "Ideologia gender a 'osobotwórcza' funkcja ciała i płci w teologii Jana Pawła II," in Idea gender jako wyzwanie dla teologii, ed. Anroni Jucewicz and Marian Machinek (Olsztyn: Hosianum, 2009), 94-96. 
removes - their procreative potential. ${ }^{30}$ In this way, the dignity of parents and possible offspring is preserved.

The above arguments are basically independent of religious faith. They are reasonable and compatible with man's corporal and spiritual nature. We are not dealing with the autocracy of biology here, but with the consistent logics of ecology. The Christian culture of the body is supported by the belief about human nature as the materialized thought of God the Creator, not a chance product of evolution. Being a creature (in German: Kreatürlichkeit), every human being is the materialized thought of God - not the outcome of some accidental workings of biology. The whole creation, all creatures, especially men, carry within themselves the "language of the Logos," as card. Joseph Ratzinger puts it. And not only in the mathematical and aesthetic dimensions, but in the moral one too. Since this language can be read and understood, man can learn his moral objectives and obligations. ${ }^{31}$ Of course, it does not follow that the meanings of human biological sexuality can be read directly from biological phenomena, conditions, and facts. Human mind has to go a long way from moral experience and analysis of person's corporal and spiritual structure to the formulation of moral norms. In the words of John Paul II: "The person, by the light of reason and the support of virtue, discovers in the body the anticipatory signs, the expression and the promise of the gift of self, in conformity with the wise plan of the Creator." 32

\section{Conflict in Policymaking}

The concept of reproductive rights is closely linked with individualism. Some people maintain that human rights, in their modern form, do not reflect all human needs and aspirations, especially those concerning sex and reproduction. They claim that human rights are subject to change and elaboration. According to the Yogyakarta Principles, everyone should have "the right to develop and discuss new human rights norms and advocate their acceptance." 33 The fight for passing new sexual and reproductive rights takes place in mass media and politics. The terms sexual health, reproductive rights, and gender were not that

30 See: Humanae Vitae, 12.

31 Cf. Benedikt XVI, "Ansprache an die Teilnehmer an dem von der Päpstlichen Lateranuniversität veranstaltete Internationalen Kongress über das natürliche Sittengesetz," February 12, 2007, http://www.vatican.va/holy_father/benedict_xvi/speeches/2007/february/documents/hf_benxvi_spe_20070212_pul_ge.html, accessed August 8, 2018.

32 Veritatis Splendor, 48.

33 The Yogyakarta Principles, 27. 
often used in academic debates before. They rather served, from the very start, as the weapon in policymaking and the struggle to direct and promote the desired legislative and social changes. Supporters of the doctrine of reproductive rights are so determined to induce social changes that they are more interested in manufacturing new legal and cultural standards, and influencing international political structures and global non-governmental organizations, than in initiating and participating in rational debates on those issues. They try to influence international bodies (like the United Nations or the European Union) with various appeals and recommendations and make them pass their recommendations as internationally promoted resolutions, which could be then used to press national legislatives bodies to include them into their legal systems. That is a top-bottom strategy: inducing legislative changes on local levels by making it obligatory for them to comply with international norms, provoking in this way changes in culture and mentality of targeted societies.

Council of Europe Convention on Preventing and Combating Violence Against Women and Domestic Violence (Istanbul Convention) of 2011 can serve as the illustration of the above schemes. The Convention contains a number of regulations that are quite in harmony with the precepts of the Christian culture of the body and deserve support. For example, the objection to various forms of physical and psychological violence against women. But, in many parts of the Convention, there is the one and only true interpretation of violence given to follow; most of all, in the Article 18, recommending that the term violence is to be understood in the context of the cultural gender. ${ }^{34}$ This interpretation may change the definition of violence and desired measures against it. Anyone objecting to the Convention on the grounds of its gender perspective as the decisive factor, must face unfair, but efficient-because mass media driven-accusation that whoever rejects the Convention, supports violence against women.

Another important conflict revolves around the institution of marriage and family. Campaigners for reproductive rights mention the institution of traditional family either in negative terms, as the birthplace of hazards and oppressive stereotypes, or in the sense of the right to start one's own family and define it according to one's views, on the grounds that "families exist in diverse forms. ${ }^{135}$ It follows that persons of the same sex can found a family. ${ }^{36}$ This is diametrically opposed to the Christian culture of the body. Complementarity of the sexes demands that marriage be the union between man and woman, not

${ }^{34}$ See: Rada Europy, Konwencja Rady Europy o zapobieganiu i zwalczaniu przemocy wobec kobiet i przemocy domowej, https://rm.coe.int/168046253c, accessed February 1, 2019.

35 The Yogyakarta Principles, 24.

${ }^{36}$ Cf. Marian Machinek, "Teologiczna antropologia w konfrontacji z ideą gender," in Idea gender jako wyzwanie dla teologii, ed. Antoni Jucewicz and Marian Machinek (Olsztyn: Hosianum, 2009), 108-109. 
the union between two or any number of persons of any sex. Making diverse unions equal before law, admitting them as marriages into the public sphere and endorsing various forms of families, will seriously weaken families based on the marriage between man and woman. Furthermore, it will compromise the definition of the family as the natural and fundamental group unit of society, written into the Universal Declaration of Human Rights. It is hard to escape the impression that the key concepts of the postulated sexual and reproductive rights contrast with the Christian culture of the body, and the letter and the spirit of human rights as they were expressed in the most important declarations since the end of the Second World War.

\section{Bibliography}

Balicki, Janusz. "Globalna polityka ludnościowa. Konflikt Północ - Południe.” Saeculum Christianum 7(2) (2000): 221-224.

Benedikt XVI. "Ansprache an die Teilnehmer an dem von der Päpstlichen Lateranuniversität veranstaltete Internationalen Kongress über das natürliche Sittengesetz.” February 12, 2007. http://www.vatican.va/holy_father/benedict_xvi/speeches/2007/february/documents/hf_benxvi_spe_20070212_pul_ge.html. Accessed August 8, 2018.

Bioethics Reflection Group of COMECE. "The Term 'Sexual and Reproductive Health' and Its Meaning at International and European Levels.” In Science \& Ethics. Collection of Opinions Prepared by the Bioethical Reflection Group (COMECE: Brussels 2012), 5-29.

Bundesministerium für Justiz und für Verbraucherschutz, Strafgesetzbuch (StGB) § 218-218a. Accessed January, 31, 2019.

Chazan, Bogdan. Prawo do życia. Bez kompromisu. Interview with Maciej Müller. Kraków: Wydawnictwo WAM, 2014.

“Gaudium et spes. Konstytucja o Kościele w świecie współczesnym.” In Sobór Watykański II, Konstytucje - Dekrety - Deklaracje. Tekst łacińsko-polski. Poznań: Pallotinum 1967, 811-987.

Gerl-Falkovitz, Hanna-Barbara. Frau - Männin - Menschin. Zwischen Feminismus und Gender. Kevelaer: Butzon \& Berker, 2009.

Gocko, Jerzy. "O prawach człowieka i niektórych kontrowersjach z nimi związanych.” In Prawa człowieka. W 60. rocznicę uchwalenia Powszechnej Deklaracji Praw Człowieka-przesłanie moralne Kościoła, ed. Krzysztof Jeżyna and Tadeusz Zadykowicz. Lublin: Wydawnictwo KUL, 2010, 33-48.

John Paul II. The International Community. List do Głów Państw na Międzynarodową Konferencję na temat Zaludnienia i Rozwoju w Kairze.” March 19, 1994. In Posoborowe Dokumenty Kościoła katolickiego o matżeństwie i rodzinie, Vol. II, ed. Kazimierz Lubowicki. Kraków: Wydawnictwo M, 1999), 105-108.

Korobczenko, Karolina. "Ideologia gender a 'osobotwórcza' funkcja ciała i płci w teologii Jana Pawła II." In Idea gender jako wyzwanie dla teologii, edited by Antoni Jucewicz and Marian Machinek. Olsztyn: Hosianum, 2009, 94-96.

Kupczak, Jarosław. Teologiczna semantyka ptci. Kraków: Wydawnictwo WAM, 2013. 
Machinek, Marian. "Teologiczna antropologia w konfrontacji z ideą gender." Idea gender jako wyzwanie dla teologii, edited by Antoni Jucewicz and Marian Machinek. Olsztyn: Hosianum, 2009, 108-109.

Machinek, Marian. "Zur Kontroverse über die normative Dimension der menschlichen Leiblichkeit.” Studia Nauk Teologicznych 8 (2013): 185-193.

Paweł VI. Humanae vitae. Encyklika o zasadach moralnych w dziedzinie przekazywania życia ludzkiego. In Posoborowe Dokumenty Kościoła katolickiego o matżeństwie i rodzinie, vol. I, edited by Kazimierz Lubowicki. Kraków: Wydawnictwo M, 1999, 21-42.

Pokrywka, Marian. "Prawa reprodukcyjne." In Prawa człowieka. W 60. Rocznice uchwalenia Powszechnej Deklaracji Praw Człowieka - przesłanie moralne Kościoła, edited by Krzysztof Jeżyna and Tadeusz Zadykowicz. Wydawnictwo KUL: Lublin, 2010, 115-126.

Powszechna Deklaracja Praw Człowieka,

http://www.unesco.pl/fileadmin/user_upload/pdf/Powszechna_Deklaracja_Praw_Czlowieka.pdf. Accessed January 30, 2019.

Proclamation of Teheran, Final Act of the International Conference on Human Rights, Teheran. http://hrlibrary.umn.edu/instree/12ptichr.htm. Accessed January 30, 2019.

Rada Europy. Konwencja Rady Europy o zapobieganiu i zwalczaniu przemocy wobec kobiet i przemocy domowej. https://rm.coe.int/168046253c. Accessed February 1, 2019.

Sgreccia, Ellio. Personalist Bioethics. Foundations and Applications. Philadelphia: NCBC, 2012.

Stoller, Robert J. Sex and Gender. On the Development of Masculinity and Femininity. New York: Carnak Books, 1968.

IV Światowa Konferencja w sprawie Kobiet, Platforma Działania. http://www.tus.org.pl/up loads/dokumenty/raport_czwartej_swiatowej_konferencji_w_sprawie_kobiet_pekin_1995. pdf. Accessed January 30, 2019.

United Nations. Report of the International Conference on Population and Development. Cairo September 5-13 1994.

http://www.un.org/en/development/desa/population/events/pdf/expert/27/SupportingDocuments/ A_CONF.171_13_Rev.1.pdf. Accessed January 30, 2019.

Wojtyła, Karol. Miłość i odpowiedzialność. Lublin: TN KUL, 2001.

Zasady Yogyakarty. Zasady stosowania międzynarodowego prawa praw człowieka w stosunku do orientacji seksualnej oraz tożsamości płciowej.

https://www.kph.org.pl/publikacje/b-y_zasady.pdf. Accessed January 15, 2014.

“Zastrzeżenia Stolicy Apostolskiej.” L'Osservatore Romano (Pl) 15(11) (1994): 48.

Jan Pawel II. "Veritatis splendor. Encyklika o niektórych podstawowych problemach nauczania moralnego Kościoła." In Jan Pawet II, Veritatis splendor. Tekst i komentarze, edited by Andrzej Szostek. Lublin: Wydawnictwo KUL, 1995, 5-103. 
Marian Machinek

\title{
Droits de reproduction versus culture chrétienne du corps Deux perspectives différentes
}

\begin{abstract}
Résumé
La juxtaposition des concepts de droits sexuels et reproductifs et de l'idée de genre avec la culture chrétienne du corps, et notamment son anthropologie personnaliste, révèle une différence fondamentale entre ces deux points de vue. Le concept de droits reproductifs se caractérise par l'individualisme, en vertu duquel l'identité de genre peut être librement déterminée, et le comportement sexuel de l'individu n'est soumis à aucune norme morale, tant qu'il est conforme à la loi. Le point principal de désaccord est l'importance de la corporéité humaine dans la conception de la personne humaine: alors que dans le concept de droits reproductifs le corps reste comme ssil était «extérieur» au sujet qui s'autodétermine; dans la culture chrétienne du corps, il fait partie de la dignité de la personne en tant que dimension constitutive de cette dernière. La différence se révèle également dans la signification à accorder à l'activité sexuelle. Les tentatives d'implémentation forcée du concept de droits sexuels et reproductifs ainsi que l'inscription de la perspective du genre au niveau du droit et de la culture ne peuvent que menacer la cellule de base de la société, qui est la famille fondée sur le mariage entre une femme et un homme.

Mots-clés: droits de l'homme, droits sexuels et reproductifs, culture corporelle chrétienne, encyclique Humanae Vitae, genre, conception personnaliste de l'individu
\end{abstract}

Marian Machinek

\section{Diritti riproduttivi versus la cultura del corpo cristiano Due diverse prospettive}

\section{Sommario}

La giustapposizione dei concetti di diritti sessuali e riproduttivi e l'idea di genere culturale con la cultura del corpo cristiano insieme alla propria antropologia personalistica rivela una differenza fondamentale di questi due punti di vista. Il concetto di diritti riproduttivi è caratterizzato dall'individualismo, in base al quale l'identità di genere può essere liberamente determinata e il comportamento sessuale dell'individuo non è soggetto a norme morali fintanto che sono all'interno della legge. Il punto principale di disaccordo è l'importanza della corporeità umana nella concezione della persona umana: mentre all'interno del concetto di diritti riproduttivi il corpo rimane come se fosse «al di fuori» di un soggetto che si autodetermina : all'interno della cultura del corpo cristiano, esso fa parte della dignità della persona in quanto la sua dimensione costitutiva. La differenza si rivela anche in merito al significato da accordare all'attività sessuale. I tentativi di implementazione forzata del concetto di diritti sessuali e riproduttivi insieme alla prospettiva di genere a livello di legge e di cultura costituirebbero una minaccia per la cellula di base della società, che è la famiglia basata sul matrimonio tra una donna e un uomo.

Parole chiave: diritti umani, diritti sessuali e riproduttivi, cultura del corpo cristiano, enciclica Humanae Vitae, genere, concezione personalista dell'individuo 